
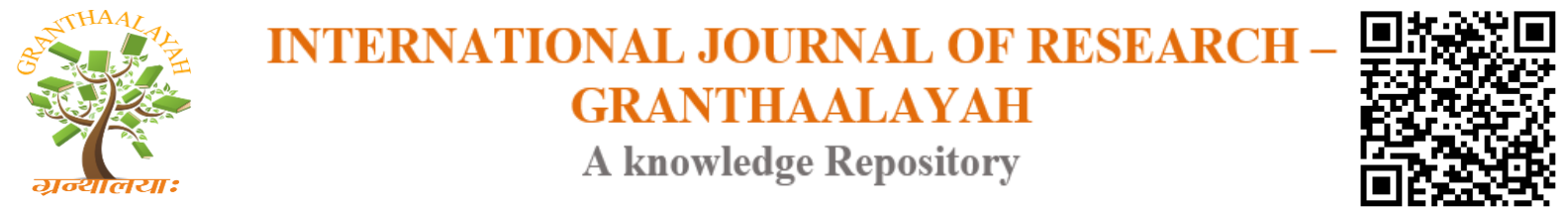

Science

\title{
GROWTH RESPONSE OF BROCCOLI (BRASSICA OLERACEA) TO DIFFERENT PLANTING DATE AT JIMMA SOUTH WESTERN ETHIOPIA
}

\author{
Essubalew Getachew ${ }^{*}$, Eba Abraham ${ }^{2}$, Wendimu Melese ${ }^{3}$ \\ ${ }^{* 1,2}$ Jimma University, College of Agriculture and Veterinary Medicine, Department of \\ Horticulture and Plant Science, P. O. Box 307, Jimma, ETHIOPIA \\ ${ }^{3}$ Jimma University, College of Agriculture and Veterinary Medicine, Income Generation Unit \\ Vegetable Crop Researcher, P. O. Box 307, Jimma, ETHIOPIA
}

DOI: https://doi.org/10.29121/granthaalayah.v4.i6.2016.2644

\section{ABSTRACT}

The current study was conducted at Jimma University College of Agriculture and Veterinary Medicine of Ethiopia to find the effect different planting date on growth performance of broccoli. Seeds were sown in well-prepared trays on 23th April, 8th March, and 23th March each in 15 days interval at the year 2016 cropping season through irrigation. Seedlings were transplanted when 3-4 true leaves were developed after 30 days. The growth parameters were measured stem girth, leaf number, leaf diameter, fresh leaf and root weight, root length, leaf length and plant height. Broccoli sowed on 23th February produced more and longer leaves, taller plant, fresh weight of roots and leaf diameter respectively. Generally, results on various parameters showed that maximum growth was obtained by planting broccoli on 23th of February. Hence, it is recommended for general cultivation of broccoli under Jimma growing condition. Moreover, as the crop is new for Jimma area further studies are needed with regard to the improvement of agronomic practices for broccoli cultivation in Jimma and similar agro ecology.

Keywords:

Broccoli, Planting date, growth parameter.

Cite This Article: Essubalew Getachew, Eba Abraham, and Wendimu Melese, "GROWTH RESPONSE OF BROCCOLI (BRASSICA OLERACEA) TO DIFFERENT PLANTING DATE AT JIMMA SOUTH WESTERN ETHIOPIA" International Journal of Research Granthaalayah, Vol. 4, No. 6 (2016): 110-118.

\section{INTRODUCTION}

Broccoli (Brassica oleracea) belongs to the genus Brassica, and family Brassicaceae which includes a wide range of crop plants derived from the Mediterranean Sea cabbage and modified over the years by selection and breeding (Decoteau, 2000). It is one of the major crop plants in 
this genus. The curd of broccoli is formed from a compact flower head and produces a green curd that rapidly develops into a mass of fertile flower buds (Biggs, 1993).

Broccoli is widely produced in many European and American countries. Broccoli is highly nutritious and has been considered as anti-cancerous food by the American Cancer society. It is a good source of vitamin $\mathrm{A}$, calcium and Vitamin $\mathrm{B}_{2}$ and it is a rich source of most minerals especially of potassium, phosphorus, sulphur and magnesium and micro elements (Aboul-Nasr and Ragab, 2000; Sanders, 1996). China is the top world producer of broccoli (FAOSTAT, 2009). Various types of vegetable crops are grown in Ethiopia under rain-fed and/or irrigation systems and this crop also included under major economically important vegetables produced and exported (Alemayehu et al., 2010)

An optimum temperature requirement of broccoli is in the range of $18-24{ }^{0} \mathrm{C}$ (Tindall, 1992; Grevsen, 1998). Growth processes show multiplicative relations with time and are thus more easily defined in terms of their relative rates (relative growth rate, net assimilation rate, etc. (Bjorkman and Pearson, 1998). Growth is a fundamental biological activity for broccoli. We can define the net growth rate of a plant as the difference between two opposing processes. One of these processes is the gross rate of gain in mass and the other the rate of loss in mass. The proportion of the new dry matter partitioned between the different plant parts and the duration of growth are important parameters to predict crop yield. The length of time for which a crop grows vegetative is an important determinant of the amount of vegetative material produced (CharlesEdwards et al., 1981).

According to Causton et al (1978) suggested that there are various advantages associated with fitting mathematical functions to plant growth data such as providing a convenient summary of the data, calculating a series of estimates of the growth attribute being less disturbed by biological variability and providing useful information if the function fitted is based on some biologically meaningful model. When plants are grown in culture the aim is often to achieve the best possible growth, by removing all environmental constraints. In other words, we provide optimum environmental conditions where the plant's inherent growth rate can be expressed (Eyffe and Titley, 1989).

The proper date of planting is one of the basic requirements for obtaining maximum yield and high return of broccoli. Unless the broccoli plant grows inappropriate weather conditions, it will not change from a vegetative to a reproductive phase, and thus it will not produce head. Weather conditions following floral initiation can also have a major effect on the quality of head. The physiological age, leaf number before curd initiation and temperature environment affect curd initiation and head quality (Tindall, 1992; Phillips and Rix, 1995). Despite of immense benefits, very little information are available regarding the planting time for commercial production of broccoli generally in Ethiopia particularly in Jimma. In Ethiopia the crop is new and no research activity were done concerning the general agronomic principles of the crop in general and effect of planting date on growth, yield and yield parameters of broccoli plants in particular. For this reason, the purpose of this activity is to investigate the effect of planting date on growth performance of broccoli at Jimma. 


\section{MATERIALS AND METHODS}

\subsection{DESCRIPTION OF EXPERIMENTAL SITE}

This study was conducted at Jimma University College of Agriculture and Veterinary Medicine, Frustales Farm and Research Centre, Jimma from end of February to May 30, 2016. Jimma is found in south western part of Ethiopia which is located at $7^{\circ} 33^{\prime}$ latitude and $36^{\circ} 57^{\prime}$ ' longitude and at the altitude of $1710 \mathrm{~m}$.a.s.l. The area receives an annual rain fall of $1500 \mathrm{~mm}$. The maximum and minimum temperatures of the area are $26.8^{9} \mathrm{c}$ and $11.4^{0} \mathrm{c}$ respectively (Essubalew et al., 2015).

\subsection{METHOD OF DATA COLLECTION AND EXPERIMENTAL DESIGN}

The experiment was laid out in Randomized Complete Block Design with three replications. Koran type heading broccoli variety was used in the study as a plating material. Seedlings were raised in module seed trays were watered early in the morning and late afternoon regularly with sprinkler till germination. Seedlings were transplanted after thirty days intervals at (3-4) true leave were produced. Each block was divided into 3 plots where 3 treatments were allotted at random. There are 9 unit plots altogether in the experiment. The size of the each plot was $2.25 \mathrm{~m}$ $\times 2.4 \mathrm{~m}$. The distance maintained between two blocks and two plots were $1 \mathrm{~m}$ and $0.5 \mathrm{~m}$, respectively. A total of $71.3 \mathrm{~m}^{2}$ was used and 20 plants per plots were planted; 200 seedling of broccoli were required. Healthy and uniform seedlings were transplant in experimental plots on plating date 1: $3^{\text {rd }}$ March, planting date 2: $18^{\text {th }}$ March and planting date 3: $3^{\text {rd }}$ April, 2016 as treatments. Seedlings were planted in the plot with maintaining distance between row to row and plant to plant was $60 \mathrm{~cm}$ and $45 \mathrm{~cm}$, respectively. After transplanting each broccoli seedling was regularly watered with a sprinkler early in the morning and early in the afternoon except rainy days. All plots were weeded with a hand hoe, twice at 2 and 4 weeks after transplanting. The field was ploughed and then exposed to sun light until the soil was friable and free from perennial weeds. Furthermore, six plants were selected from each row; those located at the middle were selected to reduce the boarder effect and data on growth parameters were collected 45 days after date of transplanting.

\subsection{DATA COLLECTED}

The measured data, at 45 days after transplanting were leaf number, plant height, root length, stem girth, fresh weight of leaves per plant, fresh weight of root per plants, leaf length and leaf width.

\subsection{DATA ANALYSIS}

The data collected in the experiment were statistically analysed with SAS Version 9.0 statistical software program. Analysis of variance (ANOVA) was done on every measured parameter to determine the significance of differences between means of treatments. Means for each parameter were separated by the least significant difference (LSD) at 5\% level of significance (Gomez and Gomez, 1984). 


\section{RESULT AND DISCUSSION}

\subsection{NUMBER OF LEAVES/PLANT}

Number of leaves/plant of broccoli was significantly affected by a different planting date. Maximum number of leaves/plant was recorded from $23^{\text {th }}$ of February; which were statistically similar with $8^{\text {th }}$ of March, while minimum number of leaves /plants was obtained from $23^{\text {th }}$ of March (Table 1). This could be due the facts that at the early planting date have favourable environmental conditions which is suitable for growth and development of broccoli. This work in line with the work of Shapla et al. (2014) and Emam (2005) reported that early planting increased number of broccoli leaves per plants.

Table 1: Effect of plating date on leaf number of broccoli at Jimma.

\begin{tabular}{ll}
\hline Planting Date & Leaf number/plant \\
\hline $23^{\text {th }}$ of February & $10^{\mathrm{a}}$ \\
$8^{\text {th }}$ of March & $7.6^{\mathrm{a}}$ \\
$23^{\text {th }}$ of March & $2.2^{\mathrm{b}}$ \\
\hline & \\
CV $(\%)$ & 23.68 \\
\hline & \\
\hline
\end{tabular}

Means followed by the same letter are not significantly different from each other at $P=0.05$.

\subsection{PLANT HEIGHT}

Plant height of broccoli varied significantly affected by a different planting date after transplanting. The tallest plant height was recorded from $8^{\text {th }}$ of March which was statistically similar with from $23^{\text {th }}$ February whereas shortest from $23^{\text {th }}$ of March (Fig.1). This due to the fact that best environmental conditions enjoyed in the field and at last date of planting seedling faced heavy rainfall that result decrease plant height. This work is in line with the research work of Emam (2005), Shapla et al (2014) and Khatun et al. (2012) in which they found that early planting increased plant height is related with the vegetative growth of the plant. 


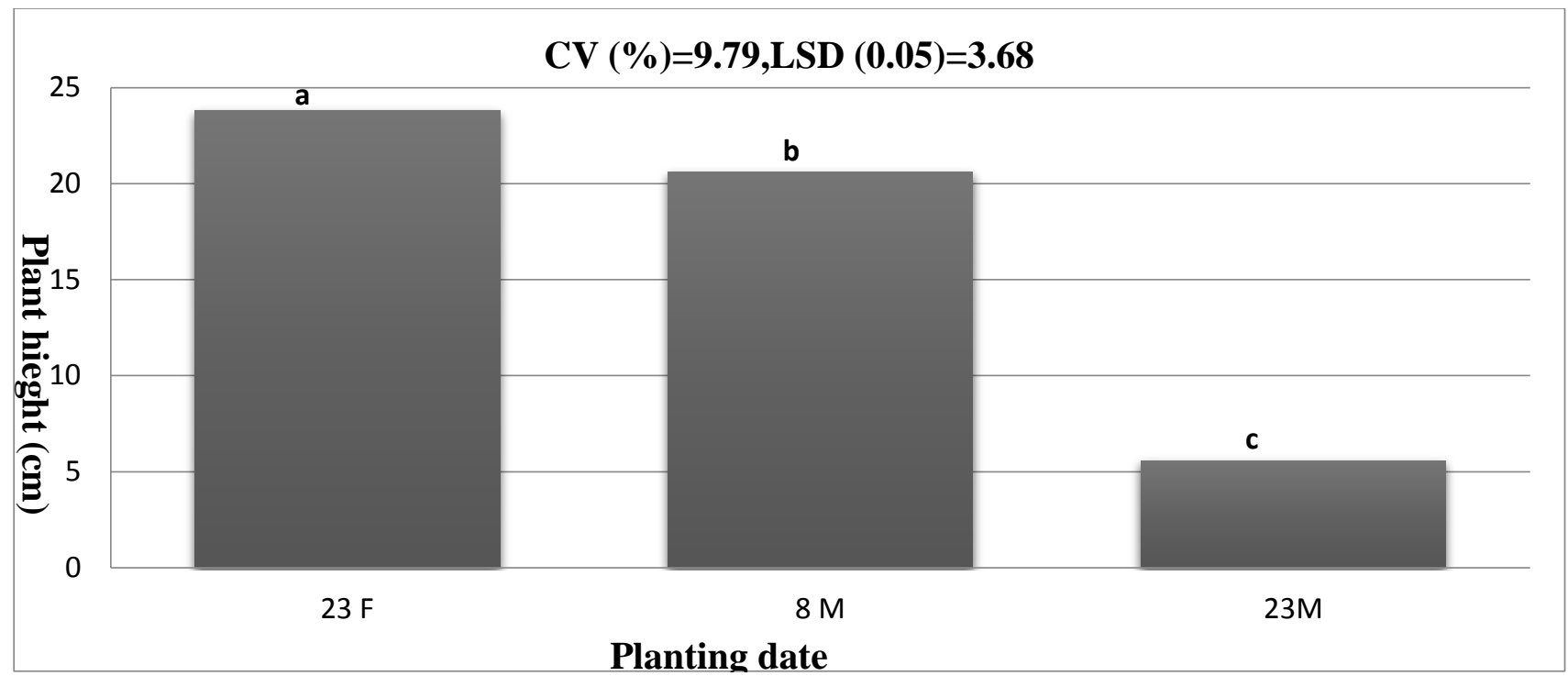

Figure 1: Effect of planting date of sowing on plant height at Jimma.

\subsection{ROOT LENGTH}

Longest root was recorded from $23^{\text {th }}$ of February which was statistically similar with $8^{\text {th }}$ of March whereas shortest from the late planting $23^{\text {th }}$ of March (Table 2). Since lengths of the root determine the whole growth of plant so the reason for the failure of the late planting date may be due to the high rainfall faced in field, which is causative agent for logging and affect the root length. This result similar with that of Khatun et al. (2012) in which he found the late date of planting of broccoli do not perform well in root length.

Table 2: Effect of date of planting on root length of broccoli at Jimma

\begin{tabular}{ll}
\hline Planting Date & Root length $(\mathbf{c m})$ \\
\hline $23^{\text {th }}$ of February & $11.13^{\mathrm{a}}$ \\
$8^{\text {th }}$ of March & $7.63^{\mathrm{b}}$ \\
$23^{\text {th }}$ of March & $1.820^{\mathrm{c}}$ \\
\hline CV $(\%)$ & 20.08 \\
\hline LSD $(\mathbf{0 . 0 1})$ & 3.1245 \\
\hline
\end{tabular}

Means followed by the same letter are not significantly different from each other at $P=0.05$.

\subsection{STEM GIRTH}

Considerable variation was recorded in terms of stem girth varied due to different planting date of broccoli. Maximum stem girth was found from $23^{\text {th }}$ of February which was statistically similar with $8^{\text {th }}$ of March while minimum was obtained from $23^{\text {th }}$ of March (Fig. 2). This might be due to the fact that a good take up of minerals and nutrients from the root for the early date of planting, since it records a high root length whereas in late planting there high water logging due to high 
rainfall. Emam (2005) and Shapla et al (2014) found that early planting increased main stem girth of broccoli.

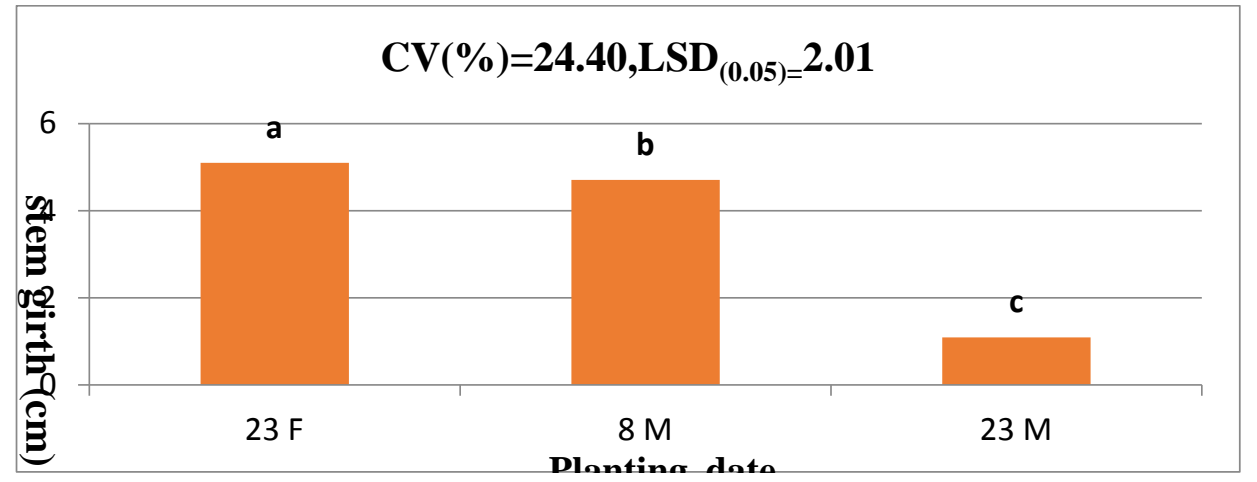

Figure 2: Effect of different planting date on stem girth of broccoli at Jimma

\subsection{FRESH WEIGHT OF LEAVES/PLANT}

Fresh weight of leaves/plant varied significantly for different planting time of broccoli. Maximum fresh weight of leaves/plant was found from $23^{\text {th }}$ of February which was statistically similar with $8^{\text {th }}$ of March. While minimum fresh weight of leaves per plant was obtained from $23^{\text {th }}$ of March (Table 3 ). Since the early planting records more number of leaves per plant which has direct relation with fresh weight of leaves. Emam (2005) and Shapla et al 2014 also reported similar findings.

Table 3: Effect of date of planting e on fresh weight broccoli leaves at Jimma

\begin{tabular}{ll}
\hline Planting Date & Fresh weight of leaf $(\mathbf{g})$ \\
\hline $23^{\text {th }}$ of February & $83.2^{\mathrm{a}}$ \\
$8^{\text {th }}$ of March & $73^{\mathrm{a}}$ \\
$23^{\text {th }}$ of March & $20.4^{\mathrm{b}}$ \\
\hline & \\
CV $(\%)$ & 23.70 \\
\hline & \\
LSD $(\mathbf{0 . 0 5})$ & 31.63 \\
\hline
\end{tabular}

Means followed by the same letter are not significantly different from each other at $P=0.05$.

\subsection{FRESH WEIGHT OF ROOTS}

Fresh weight of roots/plant varied significantly due to different planting time of broccoli. Maximum fresh weight of roots/plant was found from $23^{\text {th }}$ of February which was statistically similar with $8^{\text {th }}$ of March while minimum from $23^{\text {th }}$ of March (Fig. 3). This could be probably due to the long root recorded in planting in the early plating time. The more the length of the root, the more absorption of water and mineral and the more fresh weight of the root. This tells us the water content found in the roots of plant which is a responsible for the total growth. This 
result in line with of Khatun et al. (2012) and Emam (2005) in which also reported similar findings; they record high fresh weight of roots from their early date of sowing.

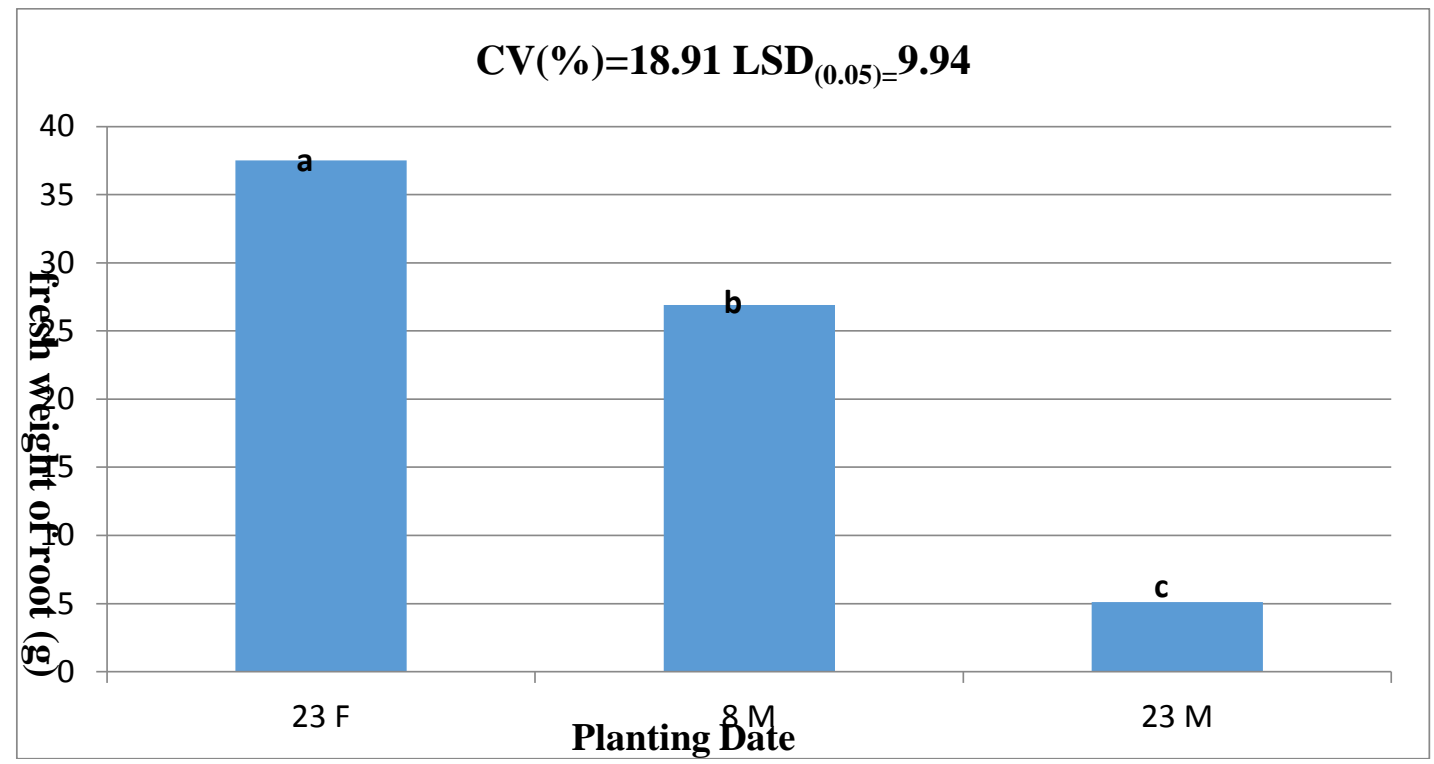

Figure 3: Effect of date of sowing on leaf fresh roots at Jimma

\subsection{LEAF LENGTH}

Leaf length varied significantly for different planting time of broccoli. Maximum leaf length was found from $8^{\text {th }}$ of March which was statistically similar with $23^{\text {th }}$ of February (Table.4). And the lowest is in $23^{\text {th }}$ March. The early date of sowing recorded more leaf length because of light harvesting than the $23^{\text {th }}$ of March and the less leaf length in late sowing may be due to cloudy weather after April to June.

Table 4: Effect of date of sowing on leaf length at Jimma

\begin{tabular}{cl}
\hline Date of sowing & Leaf length $(\mathbf{c m})$ \\
\hline $23^{\text {th }}$ of February & $21.02^{\mathrm{a}}$ \\
$8^{\text {th }}$ of March & $23.96^{\mathrm{a}}$ \\
$23^{\text {th }}$ of March & $5.53^{\mathrm{b}}$ \\
\hline CV $(\%)$ & 21.74 \\
\hline LSD $(\mathbf{0 . 0 5})$ & 8.3015
\end{tabular}

Means followed by the same letter are not significantly different from each other at $P=0.05$.

\subsection{LEAF WIDTH}

Leaf width of broccoli varied significantly at different planting time at different day after transplanting. Highest leaf diameter was recorded from $8^{\text {th }}$ of March. Whereas shortest leaf width was observed from $23^{\text {th }}$ of March (Fig.4) this might be due to high humidity of the environment at that time which creates conducive environment for pests. 


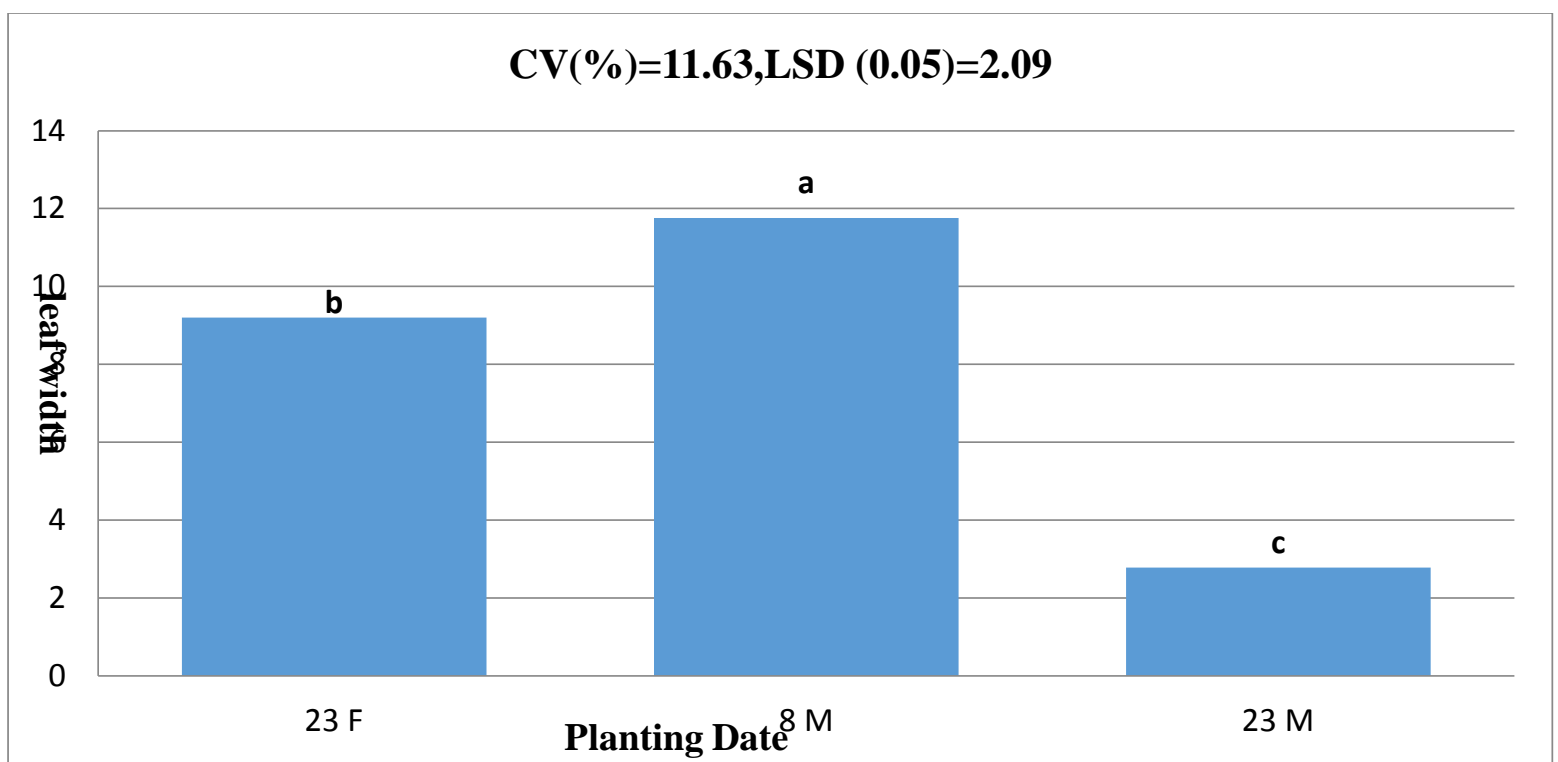

Figure 4: Effect of date of sowing on leaf width at jimma

\section{CONCLUSION AND RECOMMENDATION}

Broccoli is known as thermo sensitive crop and needs cool temperature for its optimum growth and curd formation. Its growth and curd development are greatly influenced by growing environment which was governed by time of planting. This study investigated the effects of planting dates on growth performance of broccoli through irrigation at Jimma South western Ethiopia. Broccoli sowing on $23^{\text {th }}$ February produced more and longer leaves, taller plant, and fresh weight of roots and leaf diameter. Results on various parameters showed that maximum growth was obtained by planting broccoli cultivar sprouting on $23^{\text {th }}$ of February. According to this study, we can recommend that the broccoli production through irrigation at Jimma should be selected by planting on end of February in these times because farmers would obtain higher yields as compared to than planting in other. Moreover, as the crop is new for Jimma area further studies are needed with regard to the improvement of agronomic practices for broccoli cultivation in Jimma and similar agro ecology

\section{ACKNOWLEDGMENTS}

Due appreciation is given to the Jimma University College of Agriculture and Veterinary Medicine Department of Horticulture and Plant Science for financial support and other facilities. We are particularly grateful to the farm manger Mr. Atnfu Merga for his support for planting to harvesting of the crop.

\section{REFERENCES}

[1] Aboul-Nasr, M.H. and W.S.M. Ragab, 2000. Yield, head quality and nutritional composition of a new late flowering broccoli variety grown under Assiut conditions. Assiut Journal of Agricultural Science. 31(1): 55-77

[2] Alemayehu, N.,D.Hoekstra, K.Berheandm.Jaleta(2010): Irrigated vegetable promotion and expansion: The case of Ada'a District, Oromia Region, Ethiopia. Improving the 
productivity and market success of Ethiopian Farmers (IPMS) Case Study Report, International Livestock Research Institute (ILRI), Addis Ababa, Ethiopia. Downloadable at: http://cgspace.cgiar.org/handle/10568/1422,accessed on February 11, 2014.

[3] Biggs, T.1993, vegetables. The RHS Encyclopaedia of Practical gardening. Mite bell Beazley International Ltd. Michelin Hause, London.

[4] Bjorkman,T.and K.J. Pearson.1998. High temperature arrest of inflorescence development in broccoli (Brassica oleracea var. italic L.) Journal of Experimental Botany, 49: $101-106$.

[5] Causton,D.R.,C.O. Ellis and P. Hadley. 1978. Biometrical studies of plant growth. I. The Richards function, and its application in analysing the effects of temperature on leaf Growth. Plant, Cell and Environment, I: 163-184.

[6] Charles-Edwards A.D.1981.The Mathematics of Photosynthesis and Productivity. Academic Press, London.edn.). Int. Rice Res. Inst., A Willey Int. Sci., pp. 28-192. Incalcaterra and Iapichino (2000)

[7] Damato, G., 2000. Late sowing dates and high plant density in six cultivars of broccoli for processing. Acta Horticulture., 533: 267-274

[8] Emam, M.S., 2005. Effect of transplanting date and spacing on growth, yield and head Quality of broccoli and influences of hydro cooling and wrapping on the keeping Quality of broccoli. Journal of Productivity and Development, 10(1): 75-96.

[9] Essubalew Getachew, Ali Mohammed and Abush Tesfaye. 2015. Impact of sowing date and plant spacing on yield, quality and disease incidence of Snap bean (Phaseolus vulgaris l.) varieties at Jimma Southwestern, Ethiopia. Global Advanced Research Journal of Educational Research and Review, 4(5): 081-089.

[10] Eyffe and Titley, 1989. Phenology studies and the prediction of harvest date of broccoli in the lockyer valley.Ann.Bot.,89:841-849

[11] FAO statistics, 2009. Production year book. Food and Agriculture Organization, Rome, Italy.

[12] Gomez, K.A. and A.A. Gomez. 1984. Statistical Procedure for Agricultural Research (2nd growth and yield of broccoli. J. Exp. Biosci., 3: 13-18

[13] Khatun, K. F. Hossain and S.R. Saha, 2012. Effect of different transplanting dates on the on the growth and yield of broccoli. J. Exp. Biosci., 3: 13-18

[14] Shapla S.A., Hussain M.A., Mandal M.S.H, Mehraj H. and Jamal Uddin (2014).Growth and Yield of broccoli (Brassica oleracea var. Italica L.) to different Planting times. Int. J. Bus. Soc. Sci. Res. 2(2): 95-99.

[15] Sander D.C., 1996. Broccoli production .Leaflet NO.5, NC cooperative extension service

[16] Tindall, H.D. 1992.Vegetables in the tropics. The Macmillan Press ltd. London and Basingstoke. 